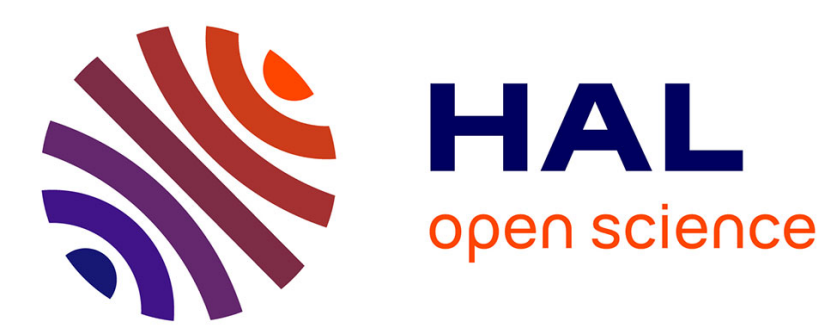

\title{
A new simple method for the synthesis of 1-alkynylphosphonates using $(\mathrm{EtO}) 2 \mathrm{P}(\mathrm{O}) \mathrm{CCl} 3$ as precursor
}

Rachel Dizière, Philippe Savignac

\section{To cite this version:}

Rachel Dizière, Philippe Savignac. A new simple method for the synthesis of 1-alkynylphosphonates using (EtO) $2 \mathrm{P}(\mathrm{O}) \mathrm{CCl} 3$ as precursor. Tetrahedron Letters, 1996, 37 (11), pp.1783-1786. 10.1016/0040-4039(96)00131-1 . hal-03166558

\section{HAL Id: hal-03166558 https://hal.science/hal-03166558}

Submitted on 11 Mar 2021

HAL is a multi-disciplinary open access archive for the deposit and dissemination of scientific research documents, whether they are published or not. The documents may come from teaching and research institutions in France or abroad, or from public or private research centers.
L'archive ouverte pluridisciplinaire HAL, est destinée au dépôt et à la diffusion de documents scientifiques de niveau recherche, publiés ou non, émanant des établissements d'enseignement et de recherche français ou étrangers, des laboratoires publics ou privés. 


\title{
A New Simple Method for the Synthesis of 1-Alkynylphosphonates using $(\mathrm{EtO})_{2} \mathrm{P}(\mathrm{O}) \mathrm{CCl} 3$ as Precursor
}

\author{
Rachel Dizière and Philippe Savignac \\ Laboratoire Hétéroéléments et Coordination associé au CNRS, DCPH, Ecole Polytechnique, \\ 91128 Palaiseau Cedex, France
}

\begin{abstract}
Alkynylphosphonates 4 were obtained from $(\mathrm{EtO})_{2} \mathrm{P}(\mathrm{O}) \mathrm{CCl}_{3} \mathbf{1}$ and aldehydes in a one-pot procedure. It involves the formation of $\alpha$-chlorovinyl phosphonate intermediates $\mathbf{3}$ by a Peterson olefination reaction followed by dehydrochlorination with LiHMDS.
\end{abstract}

Diethyl trichloromethylphosphonate $\mathbf{1}$, which is readily available on a laboratory scale ${ }^{1}$ and also commercially, has already been cited as a useful reagent. ${ }^{2}$ In preceding papers we described syntheses of medium size (4-6 membered) cycloalkylphosphonates ${ }^{3}$ and 1formylalkylphosphonates ${ }^{4}$ both relying upon the successive exchange of the three-chlorine atoms of the phosphonate $\mathbf{1}$. Based on the same approach, we would like to report in this paper our preliminary results on a promising one-pot synthesis of 1-alkynylphosphonates 4 which are of growing interest as useful synthetic intermediates. 5

Petrov in 1962, Sturtz in 1967 then Chattha and Aguiar in 1971, reported the synthesis of 1-alkynylphosphonates via an alkylation strategy between halophosphates and salts (Na, $\mathrm{Mg}$ ) of terminal alkynes. ${ }^{6}$ It is currently the best alternative to the present synthesis, however this method, in terms of generality, is closely dependent on the availability of the acetylenic substracts $\mathrm{R}-\mathrm{C} \int \mathrm{C}-\mathrm{H}$ and moreover yields are only reasonable (51-70\%). Other routes are rather elaborated and / or give low overall yields. ${ }^{7}$

Our method is based on the formation of $\alpha$-chlorovinylphosphonates via a Peterson reaction followed by dehydrochlorination to generate the triple bond. It can be described in a three-step sequence (Scheme 1). In the first step, addition of a mixture of diethyl trichloromethylphosphonate $\mathbf{1}$ and chlorotrimethylsilane to butyllithium (2.1 equiv.) in tetrahydrofuran at low temperature takes place through a double chlorine - lithium exchange conducing to the stabilized $\alpha$-phosphorylated $\alpha$-silylated $\alpha$-chlorinated carbanion $2\left[\delta_{\mathrm{P}}(\mathrm{THF})\right.$ $+46.9]$. 


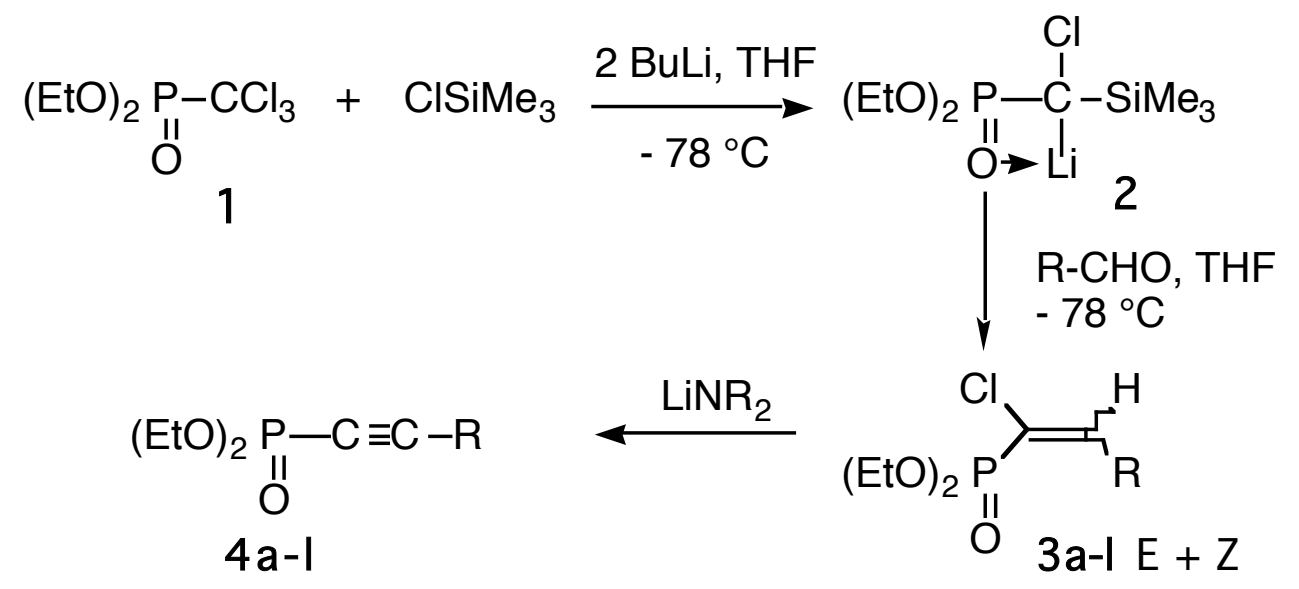

Scheme 1

Carbanion 2 can be trapped at $-78{ }^{\circ} \mathrm{C}$ with a variety of aldehydes (aromatic, heteroaromatic, aliphatic saturated or unsaturated) yielding $\alpha$-silylated $\alpha$-chlorinated $\beta$ lithiatedhydroxyphosphonates which spontaneously eliminate via a Peterson olefination reaction to give in quantitative yield an isomeric mixture of the two expected $\alpha$ chlorovinylphosphonates 3 easily identified by ${ }^{31} \mathrm{P}$ NMR analysis $\left[\delta_{\mathrm{P}}(\mathrm{THF})(\mathrm{E}) \boldsymbol{A}+11\right.$ and (Z) $\mathbf{A}+7$ ]. We assumed that the vinylic proton of $\mathbf{3}$ was acidic enough to be removed by a base. Three lithiated amides, LDA, LiTMP and LiHMDS were tested at low temperature with compound 3a $(\mathrm{R}=\mathrm{Ph})$. LDA was not usable here because it gives not only the compound $\mathbf{4 a}$ but also by-products detected by ${ }^{31} \mathrm{P}$ analysis and resulting probably from nucleophilic attack on the generated Michael acceptor 4a. Being more bulky, LiTMP and LiHMDS both give a clean and selective conversion without contamination of the products 4 . We selected LiHMDS (1.5 equiv) which is cheaper than LiTMP and easily eliminated on acidic work-up so increasing the ease of isolation of the products. The evolution of the reaction being monitored by ${ }^{31} \mathrm{P}$ NMR spectroscopy, we observed that 1-alkynylphosphonates 4 , which appeared at high field in ${ }^{31} \mathrm{P}$ NMR analysis $\left[\delta_{\mathrm{P}}(\mathrm{THF})\right.$ - -6$]$, are rapidly generated from the (Z) isomer through an anti-dehydrochlorination reaction whereas the (E) isomer is consumed more slowly. When $\mathrm{R}$ is aromatic (4a-f) the temperature of the reaction mixture is slowly elevated from $-78^{\circ} \mathrm{C}$ to $0{ }^{\circ} \mathrm{C}$ and hydrolysed at that temperature; during the process it appeared a slight brownish coloration which disappeared on acidic treatment. By contrast when $\mathrm{R}$ is heteroaromatic (4g-l) the reaction mixture is kept at low temperature all along the reaction before hydrolysis otherwise on warming we observe a dark brown colour corresponding to the decomposition of compounds 4 . As could be expected when $\mathrm{R}$ is aliphatic, the vinylic proton of $\mathbf{3}$ is much less reactive than previously and we obtained $\mathbf{4}$ mixed with by-products resulting from Michael addition type reaction. We are currently extending the field of bases to inorganic or covalent bases in order to generalize the utility of the process. All the 1-alkynylphosphonates 4 reported in Table 1 were isolated with very good yields $(87-96 \%)$ and high purity after purification by bulb-to-bulb distillation or chromatography. 
Table 1. Characteristics of 1-Alkynylphosphonates 4a-l

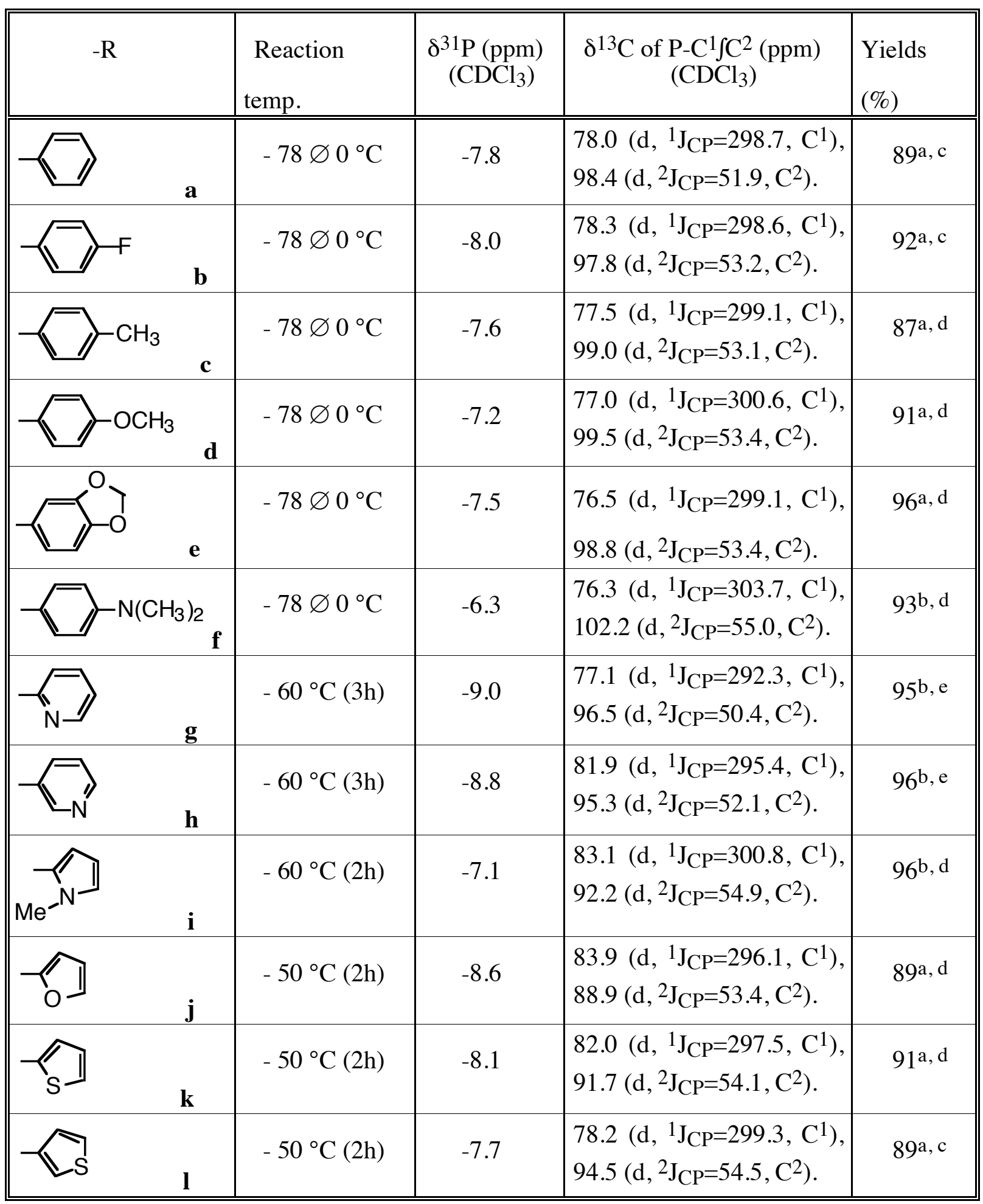

\footnotetext{
${ }^{a}$ Work-up with $2 \mathrm{~N} \mathrm{HCl}$

$\mathrm{b}$ Work-up with a saturated solution of $\mathrm{NH}_{4} \mathrm{Cl}$

${ }^{c}$ Purified by distillation (appropriated for 4 if b. p. of corresponding R-CHO $\leq 200{ }^{\circ} \mathrm{C}$ )

$\mathrm{d}$ Purified by chromatography (hexane / AcOEt)

e Crude yield : product unstable toward distillation and too polar for purification by chromatography.
} 


\section{ACKNOWLEDGMENTS}

We gratefully acknowledge the financial support by the Centre National de la Recherche Scientifique for one of us (R. D.).

\section{REFERENCES}

1. Kosolapoff, G. M. J.Am.Chem.Soc. 1947, 69, 1002-1003.

2. (a) Seyferth, D.; Marmor, R. S. J.Organomet.Chem. 1973, 59, 237-245. (b) Normant, J. F.; Perriot, P.; Villieras, J. Synthesis 1975, 458-461. (c) Coutrot, P.; Laurenco, C.; Normant, J. F.; Perriot, P.; Savignac, P.; Villieras, J. Synthesis 1977, 615-617. (d) Villieras, J.; Reliquet, A.; Normant, J. F. Synthesis 1978, 27-29. (e) Villieras, J.; Perriot, P.; Normant, J. F. Synthesis 1978, 29-31. (f) Villieras, J.; Perriot, P.; Normant, J. F. Synthesis 1978, 31-33. (g) Perriot, P.; Villieras, J.; Normant, J. F. Synthesis 1978, 33 34. (h) Lowen, G. T.; Almond, M. R. J.Org.Chem. 1994, 59, 4548-4550.

3. Grandin, C.; Collignon, N.; Savignac, P. Synthesis 1995, 239-241.

4. Zanella, Y.; Berté-Verrando, S.; Dizière, R.; Savignac, P. J. Chem. Soc. Perkin Trans. I 1995, 2835-2838.

5. (a) Saunders, B. C.; Simpson P. J.Chem. Soc. 1963, 3351-3360. (b)Minami, T.; Motoyoshima, J. Synthesis 1992, 333-349. (c) Mikolajczyk, M.; Balczewski, P. Advances in Sulfur Chemistry: Block, E. Ed.; Jai Press, 1994; pp. 41-96. (d) Ruder, S. M.; Norwood, B. K. Tetrahedron Lett. 1994, 35, 3473-3476. (e) Ma, C.; Lu, X.; Ma, Y. J.Chem. Soc. Perkin Trans 1 1995, 2683-2684.

6. (a) Ionin, B. I.; Petrov, A. A. Zh. Obshch. Khim. 1962, 32, 2387-2388; Chem. Abstr. 1963, 58, 9115b. (b) Ionin, B. I.; Lebedev, V. B.; Petrov, A. A. Dokl. Akad. Nauk SSSR 1963, 152, 1354-1356; Chem. Abstr. 1964, 60, 1560d. (c) Sturtz, G.; Charrier, C. C. R. Acad. Sci. 1965, 261, 1019-1021. (d) Sturtz, G. Bull. Soc. Chim. Fr. 1967, 1345-1353. (e) Chattha, M. S.; Aguiar, A. M. J. Org. Chem. 1971, 36, 2719-2720.

7. (a) Anisimov, K. N.; Nesmeyanov, A. N. Izv. Akad. Nauk SSSR, Otds. Khim. Nauk 1955, 1006-1008; Chem. Abstr. 1956, 50, 11267h. (b) Pudovik, A. N.; Aladzheva, I. M. Zh. Obshch. Khim. 1963, 33, 707-708; Chem. Abstr. 1963, 59, 2851f. (c) Shen, Y.; Lin, Y.; Xin, Y. Tetrahedron Lett. 1985, 26, 5137-5138. (d) Hägele, G.; Goudetsidis, S.; Wilke, E.; Seega, J.; Blum, H.; Murray, M. Phosphorus, Sulfur, and Silicon 1990, 48, 131. (e) Shen, Y.; Qi, M. J. Chem. Soc. Perkin Trans. I 1993, 2153-2154. (f) Midura, W. H.; Mikolajczyk, M. Tetrahedron Lett. 1995, 36, 2871-2874. 